\section{Food Quality and Nutritional Profile of Students of a Public School}

\author{
Loriana L Teixeira, Estelamar MB Teixeira*, Helen Mara \\ Gomes and Lucas Arantes Pereira \\ Instituto Federal de Educação, Ciência e Tecnologia do Triângulo \\ Mineiro - IFTM, Uberaba, Brazil
}

one-fifth of children and one-third of teens [1]. Food consumption is related to obesity, including not only the volume of food intake but also the quality of diet [2]

In this context, public health policies work as a tool for governments around the world to reverse the epidemiological situation [3] School Health Programs aim at development of promotion, prevention, and health care in the school environment, besides monitoring the nutritional status of students [4]. At school, children can try other foods and new preparations, and change eating habits [5].

In this context, the National School Feeding Program (PNAE) has proposed to meet the nutritional needs of students during their stay in school to contribute to food security and nutrition [6].

Besides contributing to nutrient supply, foods served in school meals should be safe from the microbiological point of view [7].

According to the Ministry of Health [8] 8,451 foodborne disease outbreaks have been reported between 2000 and 2011, of which 657 occurred in the school environment.

Food handling practices in the school environment can minimize the risk of foodborne disease outbreaks in school meals [9].

Therefore, the present study aimed to evaluate the nutritional status of children and adolescents (aged 7-16 years) in a state school in Uberaba MG / Brazil; to compare macro and micronutrients in school menu and the recommendations by PNAE; and to study the microbiological profile of the samples.

\section{Methodology}

\section{Population}

This research is a descriptive cross-sectional study including children and adolescents. Data were collected during the school year of 2014 and first half of 2015. The school Director was asked to select all students enrolled in the afternoon shift. Five hundred and forty-seven (547) students of the state school, of both sexes aged 7 to 16 years were assessed.

In this research, only the food ingestion made at the school was considered, in order to verify if the meals offered by the school meet the percentage of nutrients recommended by the PNAE.

The study was approved by the Ethics and Research Committee of the Universidade Federal do Triângulo Mineiro - Brazil, register number 877.724 and the inclusion of students in the study occurred only after obtaining the Term of Consent signed by parents or guardians.

\section{Identification questionnaire}

A structured questionnaire was used to assess the name, sex, and birth date of the participants according to the school enrollment registers. Age was calculated as the difference between anthropometric measurement and birth dates.

\section{Nutritional status}

To calculate the Body Mass Index (BMI) and characterize the nutritional status, an anthropometric evaluation from measurements of 
weight $(\mathrm{kg})$ and height $(\mathrm{m})$ was performed.

The weight measurements were carried out in a platform electronic scale (Filizola), with $300 \mathrm{~kg}$ capacity and height measurements were done using an inelastic tape measuring $1.5 \mathrm{~m}$ length, fixed to the wall at 1 meter from the floor. For the experiment, individuals dressed light clothes and did not wear shoes. Individuals were classified according to Body Mass Index (BMI). Body mass index (BMI) was calculated by dividing weight $(\mathrm{kg})$ by height squared $\left(\mathrm{m}^{2}\right)$.

The $\mathrm{Z}$ score is considered an effective method to study population, since age and gender factors are taken into account [10]. $\mathrm{Z}$ score is given by the ratio of the difference between the value measured at the individual and the value of the reference population, divided by the standard deviation of the same population [11], according to the following formula:

\section{$Z$ Score $=\frac{\text { Observed Value }- \text { Average of reference population }}{\text { Standard deviation of reference population }}$}

Anthropometric indexes used to assess the nutritional status of students aged 6-10 years were weight for age (W/A), height for age $(\mathrm{H} / \mathrm{A})$, and $\mathrm{BMI}$ for age (BMI / A) measured as $\mathrm{Z}$ scores. Height for age $(\mathrm{H} / \mathrm{A})$ and $\mathrm{BMI}$ for age (BMI / $\mathrm{A})$ measured as $\mathrm{Z}$ scores were used to evaluate the nutritional status of students aged 11-17 years.

The classification criterion used was the recommended by WHO, and adopted by the Brazilian Ministry of Health [11], as shown in table 1 and 2.

\begin{tabular}{|c|c|c|c|}
\hline \multirow[b]{2}{*}{ Critical Values } & \multicolumn{3}{|c|}{ Anthropometric Index } \\
\hline & $\begin{array}{l}\text { Weight for } \\
\text { Age }\end{array}$ & Height for Age & $\begin{array}{c}\text { BMI for } \\
\text { Age }\end{array}$ \\
\hline$<Z$ score -3 & $\begin{array}{c}\text { Severely } \\
\text { underweight }\end{array}$ & $\begin{array}{l}\text { Severely } \\
\text { stunted }\end{array}$ & $\begin{array}{l}\text { Severely } \\
\text { wasted }\end{array}$ \\
\hline$\geq Z$ score $Z-3<Z$ score -2 & Underweight & Wasted & Wasted \\
\hline$\geq Z$ score -2 e $<$ score -1 & \multirow{3}{*}{$\begin{array}{c}\text { Adequate } \\
\text { weight for age }\end{array}$} & \multirow{5}{*}{$\begin{array}{l}\text { Adequate height } \\
\text { for age }\end{array}$} & \\
\hline$\geq Z$ score $-1 \leq Z$ score +1 & & & Eutropila \\
\hline$>Z$ score $+1 \leq Z$ score +2 & & & Overweight \\
\hline$>$ Z score $+2 \leq Z$ score +3 & \multirow{2}{*}{$\begin{array}{l}\text { High weight } \\
\text { for age }\end{array}$} & & Obesity \\
\hline$>Z$ score +3 & & & $\begin{array}{l}\text { Severly } \\
\text { obesity }\end{array}$ \\
\hline
\end{tabular}

Table 1: Nutritional status of children aged 5-10 years for each anthropometric index.

Source: Adapted from Ministry of Health [11]

\begin{tabular}{|c|c|c|}
\hline \multirow{2}{*}{ Critical Values } & \multicolumn{2}{|c|}{ Anthropometric Index } \\
\hline & Weight for Age & Height for Age \\
\hline$<\mathrm{Z}$ score -3 & Severly stunted & Severly wasted \\
\hline$<Z$ score -3 e $<Z$ score -2 & Stunted & Wasted \\
\hline$<Z$ score -2 e $<Z$ score -1 & \multirow{5}{*}{ Adequate height for age } & \multirow{2}{*}{ Eutrophia } \\
\hline$<Z$ score -1 e $\leq Z$ score +1 & & \\
\hline$<Z$ score +1 e $\leq Z$ score +2 & & Overweight \\
\hline$<Z$ score +2 e $\leq Z$ score +3 & & Obesity \\
\hline$>$ Z score +3 & & Severe obesity \\
\hline
\end{tabular}

Table 2: Nutritional status of adolescents for each anthropometric index.

Source: Adapted from Ministry of Health [11]

\section{Nutrition analysis of school meals}

Weekly menus of the full month of June, 2015 were studied. French bread was served in the morning throughout the research period, together with chocolate milk or mate tea. Menus for lunch and afternoon snack were prepared for five weeks, returning to the beginning of the menu after the fifth week.

Diet Win software [12] was used to calculate the nutrients and energy consumed by students in school meals, after updating the information about nutrients and portion sizes and registering receipts. For registration of recipes not included in the software, a food composition table developed by the Center for Studies and Research in Food NEPA, Universidade Estadual de Campinas - Unicamp [13] was used.

Energy, macronutrients (carbohydrates, proteins, and lipids), fiber, vitamins $\mathrm{A}$ and $\mathrm{C}$, and minerals (calcium, iron, magnesium and zinc) intake was investigated, as suggested by PNAE.

The analyses on nutrient intake according to students' needs were carried out using the values set by PNAE as a reference. Table 3 shows the PNAE recommendations for students according to age group.

\begin{tabular}{|c|c|c|c|}
\hline \multirow{2}{*}{$\begin{array}{c}\text { Energy and } \\
\text { Nutrients }\end{array}$} & \multicolumn{3}{|c|}{ Age group } \\
\hline & 06 to 10 & 11 to 15 & 16 to 18 \\
\hline Energy (kcal) & 1000 & 1500 & 1700 \\
\hline Carbohydrate $(\mathrm{g})$ & 162.5 & 243.8 & 276.3 \\
\hline Protein $(\mathrm{g})$ & 31.2 & 46.9 & 50.0 \\
\hline Lipids (g) & 25.0 & 37.5 & 42.5 \\
\hline Fiber (g) & 18.7 & 21.1 & 22.4 \\
\hline Vitamin $A(\mu g)$ & 350.0 & 490.0 & 560.0 \\
\hline Vitamin C (mg) & 26.0 & 42.0 & 49.0 \\
\hline $\mathrm{Ca}(\mathrm{mg})$ & 735.0 & 910.0 & 910.0 \\
\hline $\mathrm{Fe}(\mathrm{mg})$ & 6.3 & 7.5 & 9.1 \\
\hline $\mathrm{Mg}(\mathrm{mg})$ & 131.0 & 222.0 & 271.0 \\
\hline $\mathrm{Zn}(\mathrm{mg})$ & 4.7 & 6.3 & 7.0 \\
\hline
\end{tabular}

Table 3: Reference values for energy and nutrients, according to age group, established by the National School Feeding Program (PNAE) to meet $70 \%$ of the daily nutritional needs.

Source: National School Feeding Program - PNAE [7]

\section{Statistical analysis}

Data to assess the nutritional status were processed in Microsoft Office Excel 2007 software; the Diet Win software [12] was used to calculate macro and micro nutrients in school meals.

\section{Results}

\section{Nutritional status}

The results for the nutritional status of the students $(\mathrm{n}=547)$, based on the body mass index $\mathrm{Z}$ scores are shown in Table 4 . There was a prevalence of $10.9 \%$ overweight $(\geq 1 \mathrm{Z}<2)$ and $3.2 \%$ obesity $(\geq 2$ $\mathrm{Z} \leq 3$ ) among students. A percentile of $0.9 \%$ students was classified with severe obesity $(Z>3)$, while $0.18 \%$ students were classified with low weight index $(\geq-3 \mathrm{Z}<-2)$.

The number of calories consumed at breakfast, lunch, and snack was $124.87,290.48$, and $266.62 \mathrm{kcal}$, respectively. Regarding the macronutrients, carbohydrate was the most consumed item, especially at lunch, averaging $50.77 \mathrm{~g}$, while protein intake at breakfast, lunch, and snack was on average $3.85 \mathrm{~g}, 10.62 \mathrm{~g}$, and $11.6 \mathrm{~g}$, respectively. 


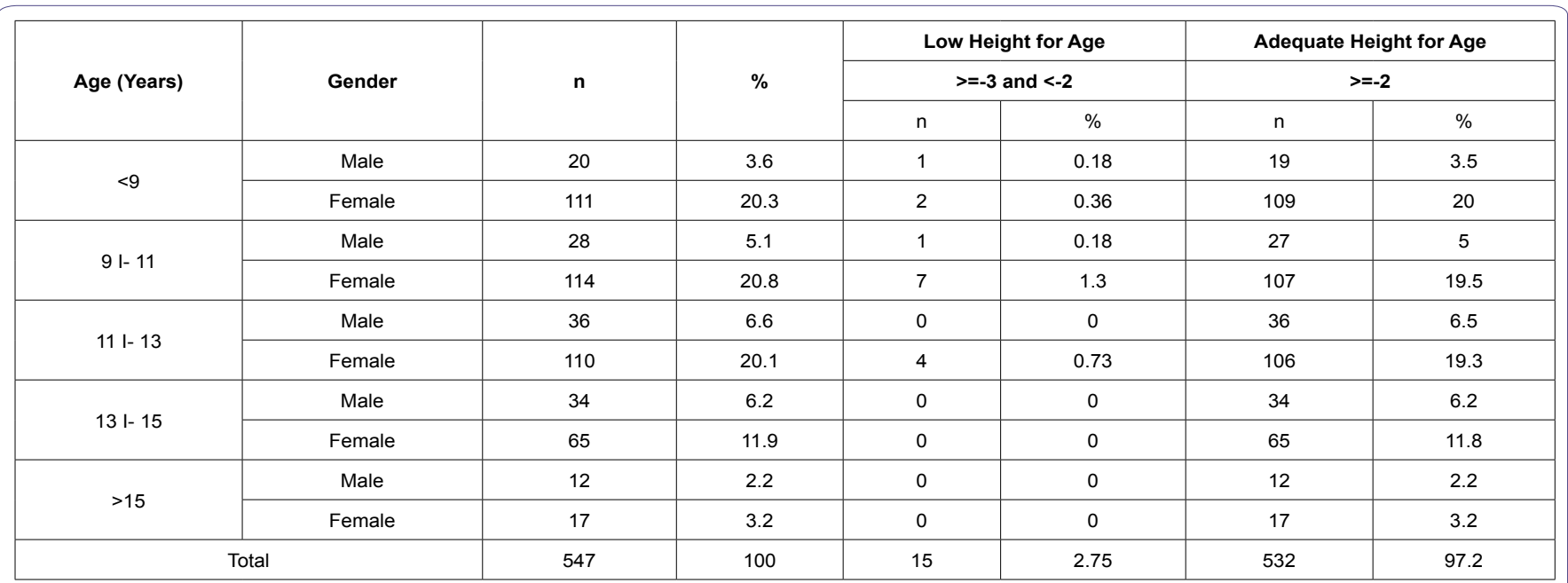

Table 4: Distribution of students according to the height-age index for children.

The classification of students according to weight-age index is shown in Table 5 . The results showed that $4.06 \%$ of female students and $0.50 \%$ of male students have high weight for age.

\begin{tabular}{|c|c|}
\hline Meal & Menu \\
\hline \multirow{2}{*}{ Breakfast } & French bread, chocolate milk \\
\hline & French bread, mate tea \\
\hline \multirow{7}{*}{ Lunch } & $\begin{array}{c}\text { Cooked white rice, cooked carioca beans, polenta bolognese, } \\
\text { lettuce salad }\end{array}$ \\
\hline & Cooked white rice, pasta with white sauce and ham \\
\hline & Cooked white rice, feijoada \\
\hline & Cooked white rice, cooked carioca beans, polenta bolognese \\
\hline & $\begin{array}{c}\text { Cooked white rice, cooked carioca beans, ground beef with } \\
\text { potato }\end{array}$ \\
\hline & Seasoned rice, chicken mayonnaise \\
\hline & $\begin{array}{l}\text { Cooked white rice, cooked carioca beans, polenta bolognese, } \\
\text { cooked cabotia pumpkin }\end{array}$ \\
\hline \multirow{8}{*}{ Snack } & Cornmeal soup \\
\hline & Cooked white rice, cooked carioca beans, crumbs banana \\
\hline & Sweet rice \\
\hline & Cooked white rice, chicken salad \\
\hline & Rice, beans drover \\
\hline & Avocado, papaya and banana smoothie \\
\hline & Vegetable soup and noodles \\
\hline & $\begin{array}{c}\text { Cooked white rice, cooked carioca beans, crumbs with ground } \\
\text { beef and cabotia pumpkin }\end{array}$ \\
\hline
\end{tabular}

Table 5: Menus used at the school during the research period.

\section{Nutritional analysis of school meals}

Table 4 - 7 shows the school menus used at the school during the research period.

Table 8 shows the average energy, macronutrients, micronutrients, fiber, calcium, iron, magnesium, zinc, and vitamins A and C intake of school meals.

The classification of students according to the height-age index is shown in Table 2. The results demonstrated that $2.75 \%$ students have low height for age.
The number of calories consumed at breakfast, lunch, and snack was $124.87,290.48$, and $266.62 \mathrm{kcal}$, respectively. Regarding the macronutrients, carbohydrate was the most consumed item, especially at lunch, averaging $50.77 \mathrm{~g}$, while protein intake at breakfast, lunch, and snack was on average $3.85 \mathrm{~g}, 10.62 \mathrm{~g}$, and $11.6 \mathrm{~g}$, respectively.

Regarding lipids intake, an increase was observed as the meals were served, from $4.21 \mathrm{~g}$ and $5.01 \mathrm{~g}$ at breakfast and lunch, respectively, reaching $8.22 \mathrm{~g}$ at afternoon snack.

A low fiber intake was verified at breakfast, with $0.56 \mathrm{~g}$, which was higher at lunch and snack, being $4.81 \mathrm{~g}$ and $4.83 \mathrm{~g}$ respectively.

A difference in vitamin A intake was also observed among the periods, with values of $32.14 \mathrm{~g}, 2.64 \mathrm{~g}$, and $9.94 \mathrm{~g}$ at breakfast, lunch, and snack, respectively.

The vitamin C intake at lunch was $4.98 \mathrm{~g}$, while at snack and breakfast the values were 4.97 and $0.58 \mathrm{~g}$, respectively.

Regarding the calcium intake, breakfast represented the highest intake, with $72.51 \mathrm{~g}$, followed by $17.95 \mathrm{~g}$ at lunch and $52.96 \mathrm{~g}$ at snack.

The average iron intake was $0.57 \mathrm{~g}, 1.3 \mathrm{~g}$, and $1.31 \mathrm{~g}$ at breakfast, lunch, and snack, respectively.

With regard to magnesium, the highest intake was observed at lunch with $38.19 \mathrm{~g}$, followed by $33.18 \mathrm{~g}$ and $13.37 \mathrm{~g}$ at snack and breakfast, respectively.

Zinc intake was higher at snack, with $2.37 \mathrm{~g}$, when compared to lunch and breakfast with values of $1.98 \mathrm{~g}$, and $0.42 \mathrm{~g}$.

Regarding the composition of school meals, the energy, macronutrients, and fiber intake was below the recommended value by PNAE, as shown in table 4 . The energy value was only $69.19 \%$ of the recommended value for the group aged 6-10 years, $45.46 \%$ for the group aged $11-15$, and $40.11 \%$ for students aged $16-18$ years. The carbohydrates intake reached $64.72 \%, 43.14 \%$, and $38.06 \%$ of the recommended value for the students aged $6-10,11-15$, and 16-18 years, respectively.

The average protein intake reached $83.5 \%$ of the recommended value for the students aged up to 10 years. In contrast, for the students aged $11-15$ and $16-18$ years, the protein intake was $55.6 \%$ and $52.14 \%$ of the recommended value, respectively. 
- Page 4 of 6 •

\begin{tabular}{|c|c|c|c|c|c|c|c|c|c|c|c|c|c|}
\hline \multirow{3}{*}{ Age (Years) } & \multirow{3}{*}{ Gender } & \multirow{3}{*}{$n$} & \multirow{3}{*}{$\%$} & \multirow{2}{*}{\multicolumn{2}{|c|}{$\begin{array}{c}\text { Low Weight } \\
\geq-3 Z<-2\end{array}$}} & \multirow{2}{*}{\multicolumn{2}{|c|}{$\begin{array}{l}\text { Eutrophia } \\
\geq-2 Z<1\end{array}$}} & \multirow{2}{*}{\multicolumn{2}{|c|}{$\begin{array}{c}\text { Overweight } \\
\geq 1 \mathrm{Z}<2\end{array}$}} & \multirow{2}{*}{\multicolumn{2}{|c|}{$\begin{array}{l}\text { Obesity } \\
\geq 2 Z \leq 3\end{array}$}} & \multirow{2}{*}{\multicolumn{2}{|c|}{$\begin{array}{c}\text { Severe Obesity } \\
z>3\end{array}$}} \\
\hline & & & & & & & & & & & & & \\
\hline & & & & & $\%$ & $\mathrm{~N}$ & $\%$ & $\mathrm{n}$ & $\%$ & $\mathrm{n}$ & $\%$ & $\mathrm{~N}$ & $\%$ \\
\hline \multirow{2}{*}{$<9$} & Male & 20 & 3.5 & 0 & 0 & 18 & 3.3 & 1 & 0.18 & 1 & 0.18 & 0 & 0 \\
\hline & Female & 111 & 20.3 & 1 & 0.18 & 97 & 17.7 & 8 & 1.5 & 5 & 0.9 & 0 & 0 \\
\hline \multirow{2}{*}{$9 \mathrm{l}-11$} & Male & 28 & 5.1 & 0 & 0 & 26 & 4.7 & 1 & 0.18 & 0 & 0 & 1 & 0.18 \\
\hline & Female & 114 & 20.8 & 0 & 0 & 89 & 16.2 & 18 & 3.3 & 6 & 1.1 & 1 & 0.18 \\
\hline \multirow{2}{*}{$11 \mathrm{I}-13$} & Male & 36 & 6.6 & 0 & 0 & 35 & 6.4 & 1 & 0.18 & 0 & 0 & 0 & 0 \\
\hline & Female & 110 & 20.1 & 0 & 0 & 96 & 17.5 & 13 & 2.4 & 1 & 0.18 & 0 & 0 \\
\hline \multirow{2}{*}{$13 \mathrm{I}-15$} & Male & 34 & 6.1 & 0 & 0 & 24 & 4.4 & 7 & 1.2 & 3 & 0.5 & 0 & 0 \\
\hline & Female & 65 & 11.9 & 0 & 0 & 54 & 9.9 & 8 & 1.4 & 2 & 0.36 & 1 & 0.18 \\
\hline \multirow{2}{*}{$>15$} & Male & 12 & 2.2 & 0 & 0 & 9 & 1.6 & 2 & 0.36 & 0 & 0 & 1 & 0.18 \\
\hline & Female & 17 & 3.2 & 0 & 0 & 13 & 2.4 & 1 & 0.2 & 2 & 0.3 & 1 & 0.18 \\
\hline \multicolumn{2}{|c|}{ Total } & 547 & 100 & 1 & 0.18 & 461 & 84.1 & 60 & 10.9 & 20 & 3.52 & 5 & 0.9 \\
\hline
\end{tabular}

\begin{tabular}{|c|c|c|c|c|c|c|c|}
\hline \multirow{3}{*}{ Age (Years) } & \multirow{3}{*}{ Gender } & \multirow{3}{*}{ n } & \multirow{3}{*}{$\%$} & \multirow{2}{*}{\multicolumn{2}{|c|}{$\begin{array}{l}\text { Adequate Weight for Age } \\
\qquad>=-2 Z<2\end{array}$}} & \multirow{2}{*}{\multicolumn{2}{|c|}{$\begin{array}{c}\begin{array}{c}\text { High Weight } \\
\text { for Age }\end{array} \\
Z>2\end{array}$}} \\
\hline & & & & & & & \\
\hline & & & & $n$ & $\%$ & $\mathrm{n}$ & $\%$ \\
\hline \multirow{2}{*}{$\leq 9$} & Male & 35 & 17.8 & 34 & 17.2 & 1 & 0.5 \\
\hline & Female & 162 & 82.2 & 154 & 78.2 & 8 & 4.06 \\
\hline \multicolumn{2}{|c|}{ Total } & 197 & 100 & 188 & 95.4 & 9 & 4.56 \\
\hline
\end{tabular}

\begin{tabular}{|c|c|c|c|}
\hline \multicolumn{5}{|c|}{ Nutrient / Meal } & Breakfast & Lunch & Afternoon Snack \\
\hline Energy (kcal) & $124.87 \pm 27.17$ & $290.48 \pm 116.52$ & $266.62 \pm 132.99$ \\
\hline $\begin{array}{c}\text { Carbohydrate } \\
\text { (g) }\end{array}$ & $17.96 \pm 2.87$ & $50.77 \pm 22.93$ & $36.45 \pm 21.79$ \\
\hline Protein (g) & $3.85 \pm 1.17$ & $10.62 \pm 4.35$ & $11.6 \pm 9.01$ \\
\hline Lipids (g) & $4.21 \pm 1.3$ & $5.01 \pm 2.76$ & $8.22 \pm 5.14$ \\
\hline Fiber (g) & $0.56 \pm 0.06$ & $4.81 \pm 2.44$ & $4.83 \pm 4.87$ \\
\hline Vitamin A & $32.14 \pm 15.00$ & $2.64 \pm 5.09$ & $9.94 \pm 14.84$ \\
\hline Vitamin C & $0.58 \pm 0.37$ & $4.98 \pm 5.83$ & $4.97 \pm 5.73$ \\
\hline Ca & $72.51 \pm 42.91$ & $17.95 \pm 8.70$ & $52.96 \pm 47.38$ \\
\hline Fe & $0.57 \pm 0.08$ & $1.3 \pm 0.84$ & $1.31 \pm 1.27$ \\
\hline Mg & $13.37 \pm 3.42$ & $38.19 \pm 30.10$ & $33.18 \pm 33.67$ \\
\hline Zn & $0.42 \pm 0.15$ & $1.98 \pm 1.12$ & $2.37 \pm 268$ \\
\hline \multicolumn{4}{|c|}{ Table 8: Energy and nutrient intake per school meal. } \\
\hline
\end{tabular}

Lipids intake was $69.76 \%$ of the recommended value for children aged 6-10 years, and $46.50 \%$ for the group aged $11-15$ years. For the group aged $16-18$ years, the average intake reached $41.03 \%$ of the recommendations.

Fiber intake was $54.5 \%, 48.3 \%$, and $45.5 \%$ of the recommended value by the PNAE for the groups aged 6-10, 11-15, and 16-18 years, respectively (Table 9 ).

The composition of micronutrients of school meals when compared to $70 \%$ of the daily nutritional needs recommended by PNAE for full day students is presented in table 10 .

Calcium intake was $19.5 \%$ and $16.8 \%$ of the recommended value for students aged 6 - 10 years and over 11 years old, respectively. Iron intake was $50.5 \%, 42.4 \%$, and $35 \%$, for the groups aged $6-10,11-15$, and 16-18 years, respectively. With respect to magnesium intake,

\begin{tabular}{|c|c|c|c|c|}
\hline \multirow{2}{*}{ Nutrient } & $\begin{array}{c}\mathbf{6}-\mathbf{1 0} \\
\text { Years old }\end{array}$ & $\begin{array}{c}\mathbf{1 1 - 1 5} \\
\text { Years old }\end{array}$ & $\begin{array}{c}\mathbf{1 6}-\mathbf{1 8} \\
\text { Years old }\end{array}$ & \multirow{2}{*}{$\begin{array}{c}\text { Provided by } \\
\text { the School }\end{array}$} \\
\cline { 2 - 4 } & $\begin{array}{c}\text { Recom- } \\
\text { mended }\end{array}$ & $\begin{array}{c}\text { Recom- } \\
\text { mended }\end{array}$ & $\begin{array}{c}\text { Recom- } \\
\text { mended }\end{array}$ & \\
\hline Energy (kcal) & 1000 & 1500 & 1700 & 681.97 \\
\hline Carbohydrate (g) & 162.5 & 243.8 & 276.3 & 105.18 \\
\hline Protein (g) & 31.2 & 46.9 & 50 & 26.07 \\
\hline Lipids (g) & 25 & 37.5 & 42.5 & 17.44 \\
\hline Fiber (g) & 18.7 & 21.1 & 22.4 & 10.2 \\
\hline
\end{tabular}

Table 9: Energy and macronutrients composition of school meals when compared to $70 \%$ of the daily nutritional needs recommended by PNAE according to age group.

\begin{tabular}{|c|c|c|c|c|}
\hline \multirow{2}{*}{ Nutrient } & $\begin{array}{c}\mathbf{6}-\mathbf{1 0} \\
\text { Years old }\end{array}$ & $\begin{array}{c}\mathbf{1 1}-\mathbf{1 5} \\
\text { Years old }\end{array}$ & $\begin{array}{c}\mathbf{1 6}-\mathbf{1 8} \\
\text { Years old }\end{array}$ & \multirow{2}{*}{$\begin{array}{c}\text { Provided by } \\
\text { the School }\end{array}$} \\
\cline { 2 - 5 } & $\begin{array}{c}\text { Recom- } \\
\text { mended }\end{array}$ & $\begin{array}{c}\text { Recom- } \\
\text { mended }\end{array}$ & $\begin{array}{c}\text { Recom- } \\
\text { mended }\end{array}$ & \\
\hline Calcium $(\mathrm{mg})$ & 735 & 910 & 910 & 143.42 \\
\hline Iron $(\mathrm{mg})$ & 6.3 & 7.5 & 9.1 & 3.18 \\
\hline Magnesium $(\mathrm{mg})$ & 131 & 222 & 271 & 84.74 \\
\hline Vitamin A $(\mu \mathrm{g})$ & 350 & 490 & 560 & 44.72 \\
\hline Vitamin C $(\mathrm{mg})$ & 26 & 42 & 49 & 10.53 \\
\hline Zinc $(\mathrm{mg})$ & 4.7 & 6.3 & 7 & 4.77 \\
\hline
\end{tabular}

Table 10: Micronutrients of school meals when compared to $70 \%$ of the daily nutritional needs recommended by PNAE.

percentages of $64.6 \%, 38.2 \%$, and $31.27 \%$ were observed for students aged 6-10, 11-15, and 16-18 years, respectively.

The average vitamin $\mathrm{C}$ intake was $40.5 \%, 25.07 \%$, and $21.5 \%$ of the recommended value by the PNAE for students aged 6-10, 11-15, and 16-18 years, while vitamin A intake reached $12.8 \%, 9.1 \%$, and $21.49 \%$ 
of the recommended value by the PNAE for those age groups, respectively.

As regards the average zinc intake for the group aged 6-10 years, the school meal supplied the recommendations proposed by the PNAE. In contrast, for those aged 11-15 years and 16-18 years, zinc intake supplied $75.7 \%$ and $68.1 \%$ of the recommended value, respectively.

\section{Discussion}

\section{Nutritional status}

Although only one school has been investigated in the present study, it followed the trend in the literature about the decline in malnutrition and increase in overweight and obesity.

Studies on obesity and underweight in school-age children and adolescents in Brazil, China, United States, and Russia have found that low weight increased only in Russia. In contrast, Brazil, China, and the United States have shown an increase in the prevalence of overweight [14].

Pegolo and Silva [15] assessed the nutritional status of school children aged 7-14 years and found $4 \%$ students with low height for age. As for the analysis of BMI, $10.7 \%$ students were underweight, while $1.6 \%$ was classified as obese.

Koga [16] investigated schoolchildren aged 7-10 years, and reported prevalence of $4.5 \%$ underweight and $11 \%$ overweight. Regarding the height for age index, stunting of $2.3 \%$ was observed.

A study in Spain found obesity in $16.8 \%$ of pre-school children aged 4 years, especially girls. The increase in chronological age raises obesity rates for $32.6 \%$ of 8 -year-old girls. A decline in female obesity is observed among teenagers, probably due to negative social connotations associated with excess body fat, since vanity is aroused in adolescence [17].

A study in Japan investigated children from primary school to high school, by evaluating weight and height every year. The results showed that approximately $50 \%$ of obese children in primary school remained obese at age 17 . At high school, $40 \%$ of obese continued overweight at age 17 , while $70 \%$ of the obese adolescents in high school remained obese at age 17 [18].

Abrantes et al., [19] studied the prevalence of overweight and obesity in children and adolescents in the Southeast and Northeast of Brazil. The results showed that $11.9 \%$ of children in the Southeast, and $8.2 \%$ in the Northeast region were obese. In adolescence, a smaller obesity was observed in the Southeast over the Northeast with $1.7 \%$ and $4.2 \%$ respectively. In this research, the prevalence of overweight and obesity was higher among women in both regions. Silva et al., [20] evaluated 211 students aged 10-19 years in Recife, Brazil, and found prevalence of $6.2 \%$ overweight and $5.7 \%$ obesity among students.

Salles et al., [21] assessed the prevalence of obesity among students aged 10-17 years in Florianópolis, Brazil, and observed a higher prevalence in public schools (13.1\%) when compared in private schools (7.6\%). In Fortaleza, Brazil, a survey assessed the nutritional status of adolescents from public and private schools. The results indicated that the prevalence of overweight and obesity in private schools reached $23.9 \%$ students, while in public schools this value was $19.5 \%$ [22].

\section{Nutritional analysis of school meals}

The results of this study showed that in relation to macronutrients, energy, and fibers, the students consumed lower amounts than recommended by the PNAE for all age groups. Regarding to micronutrients, only zinc intake for the group aged 6-10 years was adequate.

A major limitation of the study was the fact that there is no pattern in food portion sizes. PNAE recommendations are stratified by age group however meals at school are served equally for all students who receive the same menu and portion sizes. This attitude suggests a lack of guidance on the School Feeding Program, which mischaracterizes the dietary guidelines according to the nutritional needs [7].

In this research, the consumption of foods in out-of-school environments has not been studied to associate the nutritional status and food routine at home. However, the identification of insufficient nutrients and energy intake in school meals suggests that students may have a regular intake at home, since there is no major commitment in height of the students evaluated (2.75\%).

This study showed a low intake of PNAE recommendations for all nutrients (macro and micro), but indicates a high consumption of macronutrients outside the school environment according to the nutritional profile presented by the children.

Low vitamin A ingestion, with predominance among students in the public school system, and the low consumption of vitamin $\mathrm{C}$ were also recorded in other research $[23,24]$. These data are worrying, since hypovitaminosis A is considered a public health problem in Brazil and can cause night blindness, loss of vision and less resistance to infections [25]. Low vitamin C intake is associated with lower iron uptake, especially in vegetable foods [26]. The deficiencies in vitamins A and $\mathrm{C}$ are possibly due to the insufficient consumption of fruits and vegetables, and it is necessary to encourage the students to consume foods that are sources of these nutrients, prioritizing the regional ones, since they are low cost and high nutritional density.

Proportionally calcium was the nutrient with the lowest supply, and its intake was below the recommendations, which is also demonstrated in other studies $[23,27,28]$, corroborating the results of this study. Despite the favorable daily consumption of milk, the low ingestion of calcium can be due to the intake of milk in a very diluted form, with frequency and fractionation insufficient to reach the recommendation of this mineral in the organism. This improper diet practice may lead to low linear growth, impair the bone mass formation [27] and favor the early onset of osteoporosis [26].

\section{Conclusion}

The prevalence of $15 \%$ overweight (overweight, obesity, and severe obesity) among students is a warning for interventions to prevent obesity. A small group classified as underweight $(0.9 \%)$ proved to be consistent with the nutritional status in the country, where malnutrition has been replaced by excess weight.

In relation to energy and macronutrients intake, there was an insufficient intake in relation to the requirements by the PNAE for all age groups of students. It is worth mentioning the low occurrence of fibers in school meals, confirmed by fiber intake of $10.2 \mathrm{~g}$ per day, probably due to lower consumption of fruits and vegetables.

Regarding micronutrients intake, only zinc intake was within the recommended value for the group aged 6-10 years. In general, calcium, iron, vitamin A, vitamin C, magnesium intakes were considered insufficient for all ages, and zinc for the groups aged 11-15 and 16-18 years. 


\section{Acknowledgement}

Authors are thankfully acknowledges Fundação de Amparo à Pesquisa do Estado de Minas Gerais (FAPEMIG), IFTM Campus Uberaba, Escola Estadual Anexa à SUPAM and Cintia Cristina de Oliveira.

\section{References}

1. http://www.cidades.ibge.gov.br/xtras/perfil.php?lang=\&codmun=317010

2. Triches RM, Giugliani ERJ (2005) Obesidade, práticas alimentares e conhecimentos de nutrição em escolares. Revista de Saúde Pública 39.

3. Silva JRM (2010) Promoção da Saúde: Alimentação Saudável no Contexto Escolar Faculdade de Ciências da Saúde, Universidade de Brasília, Brasília, Brasil.

4. Ministério da Saúde (2009) Secretaria de Atenção à Saúde. Saúde na Escola. Cadernos de Atenção Básica, Série B Textos Básicos de Saúde, Brasília, Brasil.

5. Fisberg M, Bandeira CRS, Bonilha EA, Halpern G, Hirschbruch MD (2000) Hábitos alimentares na adolescência. Pediatria Moderna 36.

6. ftp://ftp.fnde.gov.br/web/resolucoes_2006/res032_10082006.pdf

7. https://www.fnde.gov.br/fndelegis/action/UrIPublicasAction.php?acao=getAtoPublico\&sgl_tipo=RES\&num_ato $=00000026 \&$ seq_ato $=000 \& v \mid r \_a n o=2013 \& s-$ gl_orgao=FNDE/MEC

8. http://portal.saude.gov.br/portal/arquivos/pdf/dados_dta_periodo_2000_2011_ site.pdf

9. Ministério da Saúde, Agência Nacional de Vigilância Sanitária (2004) RDC n 216. Regulamento Técnico de Boas Práticas para Serviços de Alimentação. Ministério da Saúde, Brasil.

10. de Onis M, Onyango AW, Borghi E, Siyam A, Nishida C, et al. (2007) Development of a WHO growth reference for school-aged children and adolescents. Bull world Health Organ 85: 660-667.

11. Ministério da Saúde (2011) Orientações para coleta e análise de dado antropométricos em serviços de saúde: Norma Técnica do Sistema de Vigilância Alimentar e Nutricional. Série G. Estatística e Informação à Saúde, Brasília, Brasil.

12. Brubins Comércio de Alimentos e Supergelados (2014) Dietwin: software de nutrição. Porto Alegre, Brasil.

13. Universidade Federal de Campinas (2011) Tabela Brasileira de Composição de Alimentos - TACO, $4^{\text {a }}$ edição revisada e ampliada, Núcleo de Estudos e Pesquisas em Alimentação - NEPA, Campinas, Brasil.
14. Wang Y, Monteiro C, Popkin BM (2002) Trend of obesity and underweight in older children and adolescents in the United States, Brazil, China, and Russia. Am J Clin Nutr 75: 971-977.

15. Pegolo GE, Silva MV (2008) Estado nutricional de escolares da rede pública de ensino de Peidade-SP. Segurança Alimentar e Nutricional 15.

16. Koga CR (2005) Estado nutricional de escolares de 7 a 10 anos de idade: diagnóstico e comparação de métodos. Faculdade de Saúde Pública, Universidade de São Paulo, São Paulo, Brasil.

17. Travé TD, Olascoaga JH, Torres IG (2012) Excesso de peso corporal infantil en Navarra y su repercusión en la adolescencia. Med Clin 138: 52-56.

18. Sugimori H, Yoshida K, Miyakawa M, Izuno T, Takahashi E, et al. (1999) Temporal course of the development of obesity in Japanese school children: A cohort study based on the Keio Study. J Pediatr 134: 749-754.

19. Abrantes MM, Lamounier JA, Colosimo EA (2002) Prevalência de sobrepeso e obesidade em crianças e adolescentes das regiões Sudeste e Nordeste. J Pediatr (Rio J) 78: 335-340.

20. Silva GAP, Balaban G, Nascimento EMM, Baracho JDS, Freitas MM (2002) Prevalência de sobrepeso e obesidade em adolescentes de uma escola da rede pública do Recife. Rev Bras Saúde Matern infant 2.

21. Salles RK, Kazapi IA, Di Pietro PF (2000) Ocorrência de obesidade em adolescentes da rede de ensino do município de Florianópolis. In: Obesidade e anemia carencial na adolescência: simpósio realizado em Salvador, Bahia, de 08 a 09 de junho de 2000. Instituto Danone, São Paulo, Brasil.

22. Campos LA, Leite AJM, Almeida PC (2007) Prevalência de sobrepeso e obesidade em adolescentes escolares do município de Fortaleza. Rev Bras Saude Mater Infant 7

23. Albuquerque MFM, Monteiro AM, (2002) Ingestão de alimentos e adequação de nutrientes no final da infância. Rev Nutr. 15: 291-299.

24. Maestro V (2002) Padrão alimentar e estado nutricional: caracterização de escolares de município paulista. Universidade de São Paulo, São Paulo, Brasil.

25. Ministério da Saúde, Secretaria de Atenção à Saúde (2015) Guia alimentar para a população brasileira: promovendo a alimentação saudável. Brasília Brasil.

26. Carvalho CMRG (2001) Consumo alimentar de adolescentes matriculados em um colégio particular de Teresina, Piauí, Brasil. Rev Nutr. 14: 85-93.

27. Albano RD, Souza SB (2001) Ingestão de energia e nutrientes por adolescentes de uma escola pública. J Pediatr (Rio J) 77

28. Garcia GCB, Gambardella AMD, Frutuoso MFP (2003) Estado nutricional e consumo alimentar de adolescentes de um centro de juventude da cidade de São Paulo. Rev Nutr 16: 41-50. 